Research Article

\title{
Levels of anxiety and coping with stress in healthcare workers during coronavirus disease 2019 (COVID-19) pandemic
}

Koronavirüs hastalığı 2019 (COVID-19) salgını sırasında sağlık çalışanlarında anksiyete ve stresle başa çıkma seviyeleri

\author{
(D) Deniz Deniz Ozturan ${ }^{\mathbf{a}}$ (iD) Asena Keles Sahin ${ }^{\mathbf{b}}$ \\ Department of Psychiatry, Training and Research Hospital, Ordu University, Ordu, Turkey \\ Department of Ophthalmology, Training and Research Hospital, Ordu University, Ordu, Turkey
}

\begin{abstract}
Introduction: The aim of this study is to evaluate anxiety levels and stress coping strategies of healthcare workers during the COVID-19 pandemic. Methods: Data were collected with an online survey using SurveyMonkey application. The research population comprised doctors and other medical staff living in different provinces in Turkey. The online surveys were completed by 354 healthcare workers. Demographic characteristics, severity of clinical anxiety symptoms and coping attitudes of the participants were analyzed. The Beck Anxiety Inventory (BAI) and Stress Coping Strategies Scale were used.

Results: The BAI scores of doctors were lower than those of the other healthcare workers $(p=0.037)$. When compared in terms of depression categories, the two groups were found to be similar $(\mathrm{p}=0.060)$. The levels of coping with stress were similar. The BAI scores of women were significantly higher $(\mathrm{p}=0.002)$.

Conclusion: Healthcare workers were observed to mostly develop positive coping attitudes during the COVID-19 pandemic. The results of this study suggest that the stress caused by the outbreak involves excessive load on healthcare workers psychologically.

Keywords: Coping strategies, anxiety, COVID-19, pandemic, healthcare workers
\end{abstract}

$\ddot{O} \mathbf{z}$

Giriş: Bu çalışmada, COVID-19 pandemisi sırasında sağlık çalışanlarının anksiyete düzeylerini ve stresle başa çıkma stratejilerini değerlendirmek amaçlanmıştır.

Yöntem: Veriler SurveyMonkey uygulaması kullanılarak çevrimiçi bir anket aracılığıyla toplanmıştır. Araştırma popülasyonunu Türkiye'deki farklı illerde yaşayan doktorlar ve diğer sağlık personeli oluşturdu. Çevrimiçi anketler 354 sağlık çalışanı tarafından tamamlandı. Katılımcıların demografik özellikleri, klinik anksiyete belirtilerinin şiddeti ve başa çıkma tutumları analiz edildi. Çalışmada Beck Anksiyete Envanteri (BAE) ve Stresle Baş Etme Stratejileri Ölçeği kullanıldı.

Bulgular: Doktorların BAE skorları diğer sağlık çalışanlarına göre daha düşüktü ( $\mathrm{p}=0.037)$. Depresyon kategorileri açısından karşılaştırıldığında, iki grup benzer bulundu $(\mathrm{p}=0.060)$. Stresle başa çıkma düzeyleri benzerdi $(\mathrm{p}=0.170)$. Kadınların BAE skorları anlamlı olarak yüksek bulunmuştur $(\mathrm{p}=0.002)$.

Sonuç: Sağlık çalışanlarının COVID-19 pandemisi sırasında çoğunlukla pozitif baş etme tutumları geliştirdikleri gözlenmiştir. Bu çalışmanın sonuçları, salgının neden olduğu stresin sağlık çalışanlarına psikolojik olarak aşırı yük getirdiğini göstermektedir.

Anahtar kelimeler: Baş etme stratejileri, anksiyete, COVID-19, pandemi, sağlık çalışanları

\begin{tabular}{|c|c|c|c|c|}
\hline Received & Accepted & Published Online & Corresponding Author & E-mail \\
\hline September 3, 2020 & March 18,2021 & April 3, 2021 & Asena Keles Sahin, M.D. & $\underline{\text { asina_86@hotmail.com }}$ \\
\hline Correspondence & $\begin{array}{l}\text { Dr. Asena Keles Sahin. Ordu Üniversitesi Eğitim ve Araştırma Hastanesi, Bucak Mah., Nefsi Bucak } \\
\text { Cad., 52200, Ordu, Turkey }\end{array}$ \\
\hline
\end{tabular}




\section{Introduction}

Coronavirus disease 2019 (COVID-19) first emerged in December 2019 in Wuhan City, China [1,2]. By February 2020, approximately 72,500 individuals in China were diagnosed with COVID-19, and 1800 patients died [3]. On 11 March 2020, the disease was defined as a pandemic by the World Health Organization [4].

Previous studies have shown that events, such as floods, cyclones and infectious disease epidemics trigger acute stress, anxiety, suicidal behaviour, posttraumatic stress symptoms and depression. Thus, the COVID-19 outbreak will likely trigger these symptoms [5].

The COVID-19 pandemic led healthcare workers to work under great pressure, forcing them to make difficult decisions [6]. Many healthcare workers were infected with the virus, and some of them died. Healthcare workers struggle greatly to preserve the physical and mental health of patients, treat this little-known disease and protect their health and families. Considering the lack of definite treatment and high rate of transmission, mental complaints, such as depression, anxiety and sleep disorders, are expected among healthcare workers under intense stress. Moreover, social stigma and contact with infected people have increased the stress level of healthcare workers [7]. The health and safety of health employees are important for treating patients and controlling this outbreak [8].

Stress is an adaptive behaviour to an environmental response causing psychological or physical pressure, and adaptive behaviour displays individual differences [9]. The number of studies investigating strategies for coping with stress among healthcare workers during pandemics is limited. Personality traits, such as optimism and altruism, are known to have a positive effect on coping with psychological stress [10,11]. Although individuals are psychologically affected, coping mechanisms can affect the outcomes [12]. Situations causing stress lead to uncomfortable feelings in people, and people attempt to resolve this discomfort. Individuals develop cognitive and behavioral efforts to manage stress situations. Coping strategies are defined as the process of efforts made to resolve individual unrest and to create mental equilibrium [13]. Our study aimed to evaluate anxiety levels and stress coping strategies of healthcare workers during the COVID-19 pandemic.

\section{Methods}

\section{Participants}

The cross-sectional research population comprised doctors, nurses, health personnel and medical secretaries living in different provinces in Turkey. Data were collected with an online survey using SurveyMonkey (SurveyMonkey, San Mateo, CA, USA) software between 29 April and 18 May 2020. Participating individuals were requested to complete the survey via social media (WhatsApp and Facebook). The online surveys were completed by 354 people and returned. The 62-item survey used the Beck Anxiety Inventory (BAI) and Stress Coping Strategies Scale (from the Ways of Coping Scale). To assess the demographic characteristics of the participants, their age, sex, profession, specialty (if a doctor), marital status, whether they had children and city of residence were obtained. Additionally, they were asked about COVID-19 duties and whether they or close relatives or friends were diagnosed with COVID-19. The study was approved by the Ordu University Clinical Research Ethics Committee (no: 2020/78).

\section{Scales}

\section{Stress Coping Strategies Scale}

Developed by Folkman and Lazarus [14], the validity and reliability study of the scale to Turkish language were completed by Şahin and Durak [15]. The scale was developed with the aim of measuring strategies used by individuals to cope with stress and comprises a total of 30 items. The scale consists of two subscales, problem-oriented and emotion-oriented subscales. Active approaches to the problem are self-confidence, optimism and request for social support, whereas passive approaches to emotions involve lack of self-confidence and submissive attitude. High points obtained for factors based on self-confidence, optimism and using social support are assessed as showing that active styles of coping with stress are used, while, whereas high points obtained for factors with desperate and submissive approaches show that passive styles of coping with stress are used.

\section{Beck Anxiety Inventory}

The BAI is a screening tool used with the aim of assessing anxiety and measuring the severity of anxiety. This test assesses the severity of clinical anxiety symptoms experienced by participants in the last week and comprises 21 questions with points from 0 to 3 [16]. Points obtained vary from 0 to 63 , and high points indicate more severe anxiety. In this study, the validated Turkish version of the BAI was used [17].

\section{Statistical Analysis}

All analyses were performed on SPSS v21 (SPSS Inc., Chicago, IL, USA). Histogram and Q-Q plots were used to determine whether variables are normally distributed. Data were presented as mean \pm standard deviation or median (minimum-maximum) for continuous variables according to normality of distribution and as frequency (percentage) for categorical variables. Normally and non-normally distributed variables were analyzed using the independent samples t test and Mann-Whitney $\mathrm{U}$ test, respectively. Categorical variables were analyzed using the Chi-squared tests. Results were statistically significant if $\mathrm{p}<0.05$.

\section{Results}

The mean age of the study group was $35.97 \pm 7.53$ years for females and $37.78 \pm 7.71$ years for males. Of the study group, 55.93\% ( $\mathrm{n}=198$ ) were females, 44.07\% $(\mathrm{n}=156)$ were males, 61.58\% $(\mathrm{n}=218)$ were doctors, $74.86 \%(\mathrm{n}=265)$ were married and $67.80 \%(\mathrm{n}=240)$ had a child. In addition, $32.58 \%(n=115)$ of healthcare workers had relatives with COVID-19. In the study group, $1.69 \%(n=6)$ of patients were infected with severe acute respiratory syndrome coronavirus (SARS-CoV). Individual characteristics and inventory scores are summarized in Table 1. 
Table 1. Summary of individuals characteristics and inventory scores

\begin{tabular}{|c|c|}
\hline Age $(n=352)$ & $36.77 \pm 7.66(21-61)$ \\
\hline \multicolumn{2}{|l|}{ Gender $(n=354)$} \\
\hline Female & $198(55.93 \%)$ \\
\hline Male & $156(44.07 \%)$ \\
\hline \multicolumn{2}{|l|}{ Profession $(n=354)$} \\
\hline Doctor & $218(61.58 \%)$ \\
\hline Nurse & $98(27.68 \%)$ \\
\hline Health personnel & $18(5.08 \%)$ \\
\hline Medical secretary & $18(5.08 \%)$ \\
\hline Others & $2(0.56 \%)$ \\
\hline \multicolumn{2}{|l|}{ Specialty (Doctors) $(n=218)$} \\
\hline Emergency medicine & $12(5.50 \%)$ \\
\hline Infectious diseases & $2(0.92 \%)$ \\
\hline Anesthesiology and reanimation & $14(6.42 \%)$ \\
\hline Internal medicine & $17(7.80 \%)$ \\
\hline Chest disease & $4(1.83 \%)$ \\
\hline Others & $169(77.52 \%)$ \\
\hline \multicolumn{2}{|l|}{ Marital status (n=354) } \\
\hline Married & $265(74.86 \%)$ \\
\hline Single & $85(24.01 \%)$ \\
\hline Others & $4(1.13 \%)$ \\
\hline Have child(ren) $(n=354)$ & $240(67.80 \%)$ \\
\hline \multicolumn{2}{|l|}{ City $(n=347)$} \\
\hline Ankara & $18(5.19 \%)$ \\
\hline Bolu & $12(3.46 \%)$ \\
\hline Gaziantep & $32(9.22 \%)$ \\
\hline İstanbul & $22(6.34 \%)$ \\
\hline Kocaeli & $21(6.05 \%)$ \\
\hline Ordu & $84(24.21 \%)$ \\
\hline Samsun & $27(7.78 \%)$ \\
\hline Trabzon & $26(7.49 \%)$ \\
\hline Others & $105(30.26 \%)$ \\
\hline Secondment for COVID-19 $(n=352)$ & $191(54.26 \%)$ \\
\hline COVID-19 Positive (Himself/Herself) $(n=354)$ & $6(1.69 \%)$ \\
\hline COVID-19 Positive (Family/Friend) $(n=353)$ & $115(32.58 \%)$ \\
\hline \multicolumn{2}{|l|}{ Stress Coping Strategies Scale $(n=354)$} \\
\hline Self-confident & $20.40 \pm 3.47(11-28)$ \\
\hline Optimistic & $13.71 \pm 2.59(6-20)$ \\
\hline Desperated & $16.15 \pm 3.83(8-30)$ \\
\hline Subjugation & $11.89 \pm 2.49(6-19)$ \\
\hline Social support & $12.07 \pm 1.85(6-16)$ \\
\hline Effective & $46.18 \pm 6.47(28-64)$ \\
\hline Ineffective & $28.04 \pm 5.40(15-48)$ \\
\hline \multicolumn{2}{|l|}{ Highest Score $(n=354)$} \\
\hline Self-confident & $274(77.40 \%)$ \\
\hline Optimistic & $1(0.28 \%)$ \\
\hline Desperated & $65(18.36 \%)$ \\
\hline Subjugation & $0(0.00 \%)$ \\
\hline Social support & $0(0.00 \%)$ \\
\hline Self-confident \& Optimistic & $1(0.28 \%)$ \\
\hline Self-confident \& Desperated & $12(3.39 \%)$ \\
\hline Self-confident \& Optimistic \& Desperated & $1(0.28 \%)$ \\
\hline \multicolumn{2}{|l|}{ Highest Score $(n=354)$} \\
\hline Effective & $333(94.07 \%)$ \\
\hline Ineffective & $19(5.37 \%)$ \\
\hline Equal & $2(0.56 \%)$ \\
\hline Beck Anxiety Inventory $(n=352)$ & $10.79 \pm 10.45(0-56)$ \\
\hline Minimal & $174(49.43 \%)$ \\
\hline Mild & $93(26.42 \%)$ \\
\hline Moderate & $54(15.34 \%)$ \\
\hline Severe & $31(8.81 \%)$ \\
\hline
\end{tabular}

Data are given as mean \pm standard deviation (minimum - maximum) for continuous variables and as frequency (percentage) for categorical variables. COVID-19: Coronavirus Disease 2019

The study group was divided into doctors and others based on their profession. The BAI scores of doctors were lower than those of the others (p $=0.037)$. When compared in terms of depression categories, the two groups were found to be similar $(\mathrm{p}=0.060)$. In addition, the levels of coping with stress were similar (Figure 1). Individual inventory scores with regard to profession are presented in Table 2. 


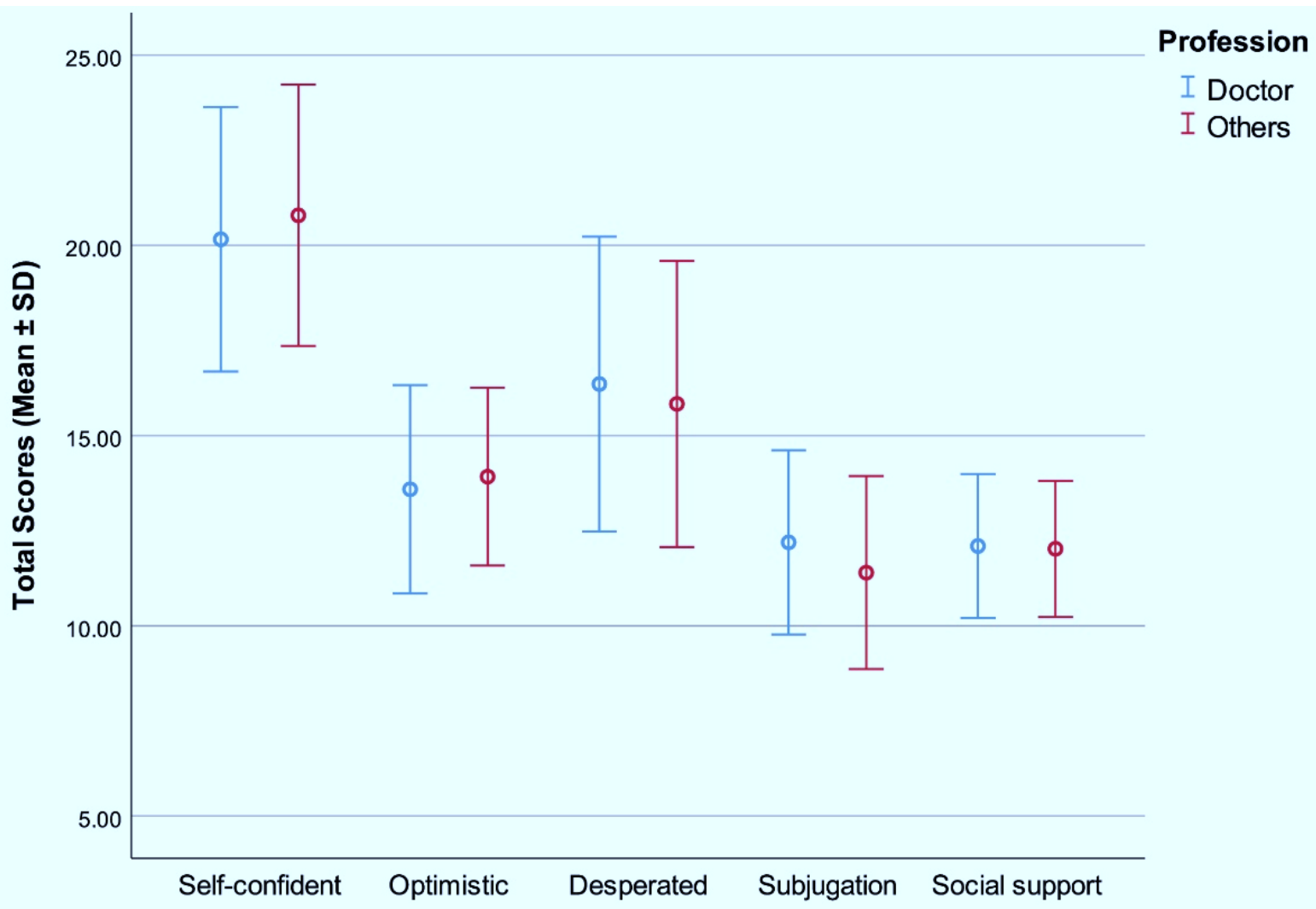

Figure 1. Ways of coping with stress according to profession

Table 2. Summary of individuals inventory scores with regard to profession

\begin{tabular}{|c|c|c|c|}
\hline & \multicolumn{2}{|c|}{ Profession } & \multirow[b]{2}{*}{$\mathrm{p}$} \\
\hline & Doctors $(\mathrm{n}=218)$ & Others $(n=136)$ & \\
\hline \multicolumn{4}{|l|}{ Stress Coping Strategies Scale } \\
\hline Self-confident & $20.16 \pm 3.47$ & $20.79 \pm 3.43$ & 0.096 \\
\hline Optimistic & $13.59 \pm 2.74$ & $13.92 \pm 2.34$ & 0.242 \\
\hline Desperated & $16.35 \pm 3.87$ & $15.83 \pm 3.76$ & 0.213 \\
\hline Subjugation & $12.19 \pm 2.42$ & $11.40 \pm 2.54$ & $0.003^{*}$ \\
\hline Social support & $12.10 \pm 1.89$ & $12.02 \pm 1.79$ & 0.714 \\
\hline Effective & $45.84 \pm 6.81$ & $46.73 \pm 5.85$ & 0.209 \\
\hline Ineffective & $28.55 \pm 5.29$ & $27.23 \pm 5.49$ & $0.025^{*}$ \\
\hline \multicolumn{4}{|l|}{ Highest Score } \\
\hline Self-confident & $163(74.77 \%)$ & $111(81.62 \%)$ & \multirow{8}{*}{0.170} \\
\hline Optimistic & $1(0.46 \%)$ & $0(0.00 \%)$ & \\
\hline Desperated & $44(20.18 \%)$ & $21(15.44 \%)$ & \\
\hline Subjugation & $0(0.00 \%)$ & $0(0.00 \%)$ & \\
\hline Social support & $0(0.00 \%)$ & $0(0.00 \%)$ & \\
\hline Self-confident \& Optimistic & $0(0.00 \%)$ & $1(0.74 \%)$ & \\
\hline Self-confident \& Desperated & $10(4.59 \%)$ & $2(1.47 \%)$ & \\
\hline Self-confident \& Optimistic \& Desperated & $0(0.00 \%)$ & $1(0.74 \%)$ & \\
\hline \multicolumn{4}{|l|}{ Highest Score } \\
\hline Effective & $201(92.20 \%)$ & $132(97.06 \%)$ & \multirow{3}{*}{0.144} \\
\hline Ineffective & $15(6.88 \%)$ & $4(2.94 \%)$ & \\
\hline Equal & $2(0.92 \%)$ & $0(0.00 \%)$ & \\
\hline Beck Anxiety Inventory & $7(0-56)$ & $9(0-55)$ & $0.037^{*}$ \\
\hline Minimal & $116(53.70 \%)$ & $58(42.65 \%)$ & \multirow{4}{*}{0.060} \\
\hline Mild & $56(25.93 \%)$ & $37(27.21 \%)$ & \\
\hline Moderate & $31(14.35 \%)$ & $23(16.91 \%)$ & \\
\hline Severe & $13(6.02 \%)$ & $18(13.24 \%)$ & \\
\hline
\end{tabular}

Normally and non-normally distributed variables were analyzed using the independent samples t test and Mann-Whitney U test, respectively. Categorical variables were analyzed using the Chi-squared tests. Data are given as mean \pm standard deviation or median (minimum - maximum) for continuous variables according to normality of distribution and as frequency (percentage) for categorical variables. COVID-19: Coronavirus Disease 2019. *Statistically significant 
The study group was divided into two according to the status of one of their relatives having COVID-19. Both groups were similar in terms of the scores from Stress Coping Strategies Scale and BAI and the categories that were formed (Table 3) (Figure 2).

Table 3. Summary of individuals inventory scores with regard to presence of COVID-19 positive relatives

\begin{tabular}{|c|c|c|c|}
\hline & \multicolumn{2}{|c|}{ COVID-19 positive (self/family/friend) } & \multirow[b]{2}{*}{$\mathrm{p}$} \\
\hline & Present $(n=116)$ & Absent $(n=237)$ & \\
\hline \multicolumn{4}{|l|}{ Stress Coping Strategies Scale } \\
\hline Self-confident & $20.65 \pm 3.10$ & $20.27 \pm 3.64$ & 0.345 \\
\hline Optimistic & $13.85 \pm 2.31$ & $13.65 \pm 2.72$ & 0.480 \\
\hline Desperated & $15.96 \pm 3.60$ & $16.23 \pm 3.95$ & 0.527 \\
\hline Subjugation & $11.83 \pm 2.54$ & $11.91 \pm 2.48$ & 0.779 \\
\hline Social support & $12.34 \pm 1.73$ & $11.93 \pm 1.90$ & 0.054 \\
\hline Effective & $46.84 \pm 5.51$ & $45.85 \pm 6.89$ & 0.149 \\
\hline Ineffective & $27.78 \pm 5.44$ & $28.14 \pm 5.38$ & 0.563 \\
\hline \multicolumn{4}{|l|}{ Highest Score } \\
\hline Self-confident & $95(81.89 \%)$ & $178(75.11 \%)$ & \multirow{8}{*}{0.660} \\
\hline Optimistic & $0(0.00 \%)$ & $1(0.42 \%)$ & \\
\hline Desperated & $17(14.66 \%)$ & $48(20.25 \%)$ & \\
\hline Subjugation & $0(0.00 \%)$ & $0(0.00 \%)$ & \\
\hline Social support & $0(0.00 \%)$ & $0(0.00 \%)$ & \\
\hline Self-confident \& Optimistic & $0(0.00 \%)$ & $1(0.42 \%)$ & \\
\hline Self-confident \& Desperated & $4(3.45 \%)$ & $8(3.38 \%)$ & \\
\hline Self-confident \& Optimistic \& Desperated & $0(0.00 \%)$ & $1(0.42 \%)$ & \\
\hline \multicolumn{4}{|l|}{ Highest Score } \\
\hline Effective & $110(94.83 \%)$ & $222(93.67 \%)$ & \multirow{3}{*}{0.724} \\
\hline Ineffective & $5(4.31 \%)$ & $14(5.91 \%)$ & \\
\hline Equal & $1(0.86 \%)$ & $1(0.42 \%)$ & \\
\hline Beck Anxiety Inventory & $8.50(0-56)$ & $7(0-55)$ & 0.102 \\
\hline Minimal & $52(44.83 \%)$ & $121(51.49 \%)$ & \multirow{4}{*}{0.427} \\
\hline Mild & $36(31.03 \%)$ & $57(24.26 \%)$ & \\
\hline Moderate & $16(13.79 \%)$ & $38(16.17 \%)$ & \\
\hline Severe & $12(10.34 \%)$ & $19(8.09 \%)$ & \\
\hline
\end{tabular}

Normally and non-normally distributed variables were analyzed using the independent samples t test and Mann-Whitney U test, respectively. Categorical variables were analyzed using the Chi-squared tests. Data are given as mean \pm standard deviation or median (minimum - maximum) for continuous variables according to normality of distribution and as frequency (percentage) for categorical variables. COVID-19: Coronavirus Disease 2019

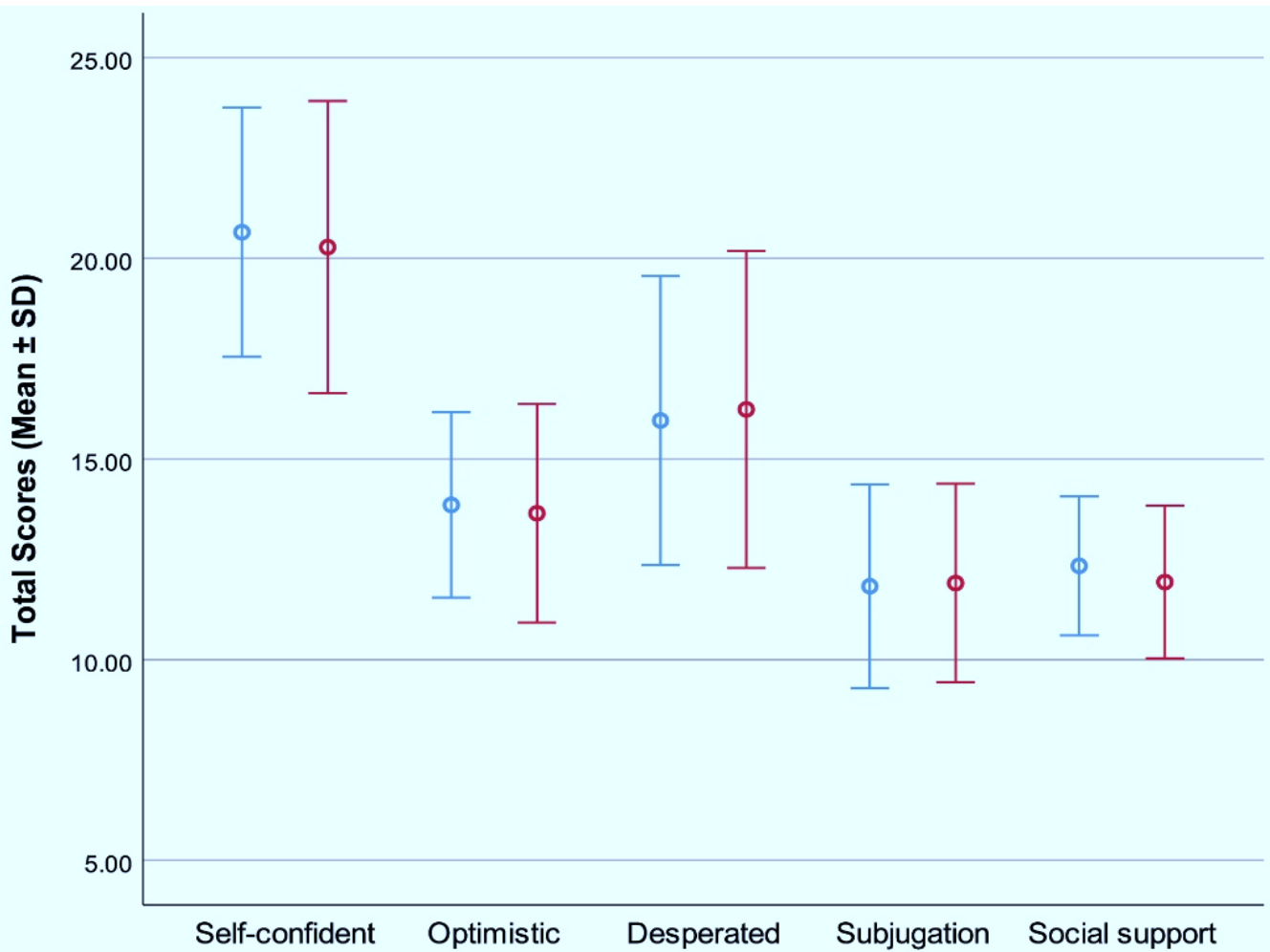

CoVID-19 positive (self/family/friend)

I Present

I Absent

Figure 2. Ways of coping with stress according to presence of COVID-19 positive relatives 
The BAI points and ways of coping of individuals based on sex are shown in Table 4. A significant difference was identified between the two groups in terms of BAI points $(\mathrm{p}=0.002)$. Anxiety rates $(57.58 \%)$ in women were higher than those in men $(41.57 \%)$. When ways of coping were assessed, men used more active coping attitudes (significant differences for self-confidence and optimism).

Table 4. Summary of individuals inventory scores with regard to gender

\begin{tabular}{|c|c|c|c|}
\hline & \multicolumn{2}{|c|}{ Gender } & \multirow[b]{2}{*}{$\mathrm{p}$} \\
\hline & Female $(n=198)$ & Male $(n=152)$ & \\
\hline \multicolumn{4}{|c|}{ Stress Coping Strategies Scale } \\
\hline Self-confident & $20.05 \pm 3.41$ & $20.84 \pm 3.49$ & $0.020^{*}$ \\
\hline Optimistic & $13.40 \pm 2.41$ & $14.11 \pm 2.76$ & $0.006 *$ \\
\hline Desperated & $16.45 \pm 3.99$ & $15.78 \pm 3.59$ & 0.083 \\
\hline Subjugation & $11.85 \pm 2.52$ & $11.93 \pm 2.47$ & 0.699 \\
\hline Social support & $12.13 \pm 1.82$ & $11.99 \pm 1.89$ & 0.154 \\
\hline Effective & $45.59 \pm 6.10$ & $46.94 \pm 6.85$ & $0.034^{*}$ \\
\hline Ineffective & $28.30 \pm 5.74$ & $27.71 \pm 4.94$ & 0.228 \\
\hline \multicolumn{4}{|c|}{ Beck Anxiety Inventory } \\
\hline Mild & $55(27.78 \%)$ & $38(24.68 \%)$ & \\
\hline Moderate & $33(16.67 \%)$ & $21(13.64 \%)$ & $0.002^{*}$ \\
\hline Severe & $26(13.13 \%)$ & $5(3.25 \%)$ & \\
\hline
\end{tabular}

Normally and non-normally distributed variables were analyzed using the independent samples $t$ test and Mann-Whitney U test, respectively. Categorical variables were analyzed using the Chi-squared tests. Data are given as mean \pm standard deviation or median (minimum - maximum) for continuous variables according to normality of distribution and as frequency (percentage) for categorical variables. COVID-19: Coronavirus Disease 2019. *Statistically significant

\section{Discussion}

In situations, such as in pandemics, there are psychological effects not just on society but also on healthcare employees working during the pandemic. Stress is expected in healthcare workers during epidemics. One of the most important sources of stress in humans is intolerance of uncertainty. As a result, the stress caused by the outbreak involves very excessive load on health employees both physically and psychologically. The outbreak will have negative psychological effects both during and after the outbreak. Just as stress was observed among healthcare workers in epidemic periods due to SARS and Middle East respiratory syndrome, studies have shown it continued after the epidemics were over [18,19]. COVID-19 is a viral disease involving many uncertainties due to lack of information, lack of definite treatment and vaccine and high rate of infection. When people encounter disasters, they develop various strategies for coping. Each individual has different attitudes to coping with stress. Some develop active coping attitudes; some have more difficulty and attempt to manage stress with passive attitudes. Managing stress is important to be healthy.

This research investigated the level of anxiety and stress coping strategies in healthcare workers living in different provinces in Turkey, during the COVID-19 pandemic. This study also investigated the effect on these variables of potentially affecting factors such as gender, presence of COVID19 positive relatives and profession.

The most important reason for anxiety in healthcare workers is that they both treat patients and protect their own health. Additionally, their stress level increases with the risk of transmission of the disease to their family from this high infection risk group. A study observed that the anxiety rate among healthcare workers was $44.55 \%$, and $>70 \%$ of healthcare workers had psychological problems, such as insomnia, anxiety and depression [20]. A study in 2020 showed that the anxiety rate among doctors was 11.39\%. In addition to low anxiety levels, a negative correlation was identified between positive coping methods and anxiety scale points [21]. Awareness of the effects of disease prevention measures with variable numbers of reported cases may explain different results in the literature. In this study, the anxiety levels in healthcare workers were mostly mild and moderate. The rate of anxiety levels among doctors were $46.30 \%$, whereas this rate was $57.36 \%$ for other healthcare workers. Additionally , healthcare workers mainly developed more positive coping attitudes and mostly used self-confident approaches among these attitudes.

In previous studies, anxiety levels are significantly higher in people with at least one family member, relative, or a friend with the COVID-19 disease [22,23]. Ozdin et al. reported the higher scores of depression and anxiety among individuals with people positive for COVID in their friends or relatives [24]. In the present study, when divided into those with or without people positive for COVID-19 in their family, no significant difference was found between the two groups in terms of anxiety and coping attitudes. The lack of a COVID-19-positive individual in their family does not mean that none will occur in the future. Therefore, healthcare workers are continually anxious about the possibility of transmission during the outbreak.

Various studies that have examined the psychological disorders during the COVID-19 pandemic have reported that the affected individuals show several symptoms of mental trauma, such as depression, stress, insomnia and post-traumatic stress [25,26]. Early identification of psychological problems will lead to earlier resolution of the problems, will increase resistance when fighting the pandemic and will have positive effects both socially and clinically [27]. Health crises such the COVID-19 pandemic lead to psychological changes, not only in the citizens, but also in the healthcare workers. A study in China showed that, especially, first-line healthcare workers dealing directly with the outbreak were under more stress and psychological pressure [28]. The personal coping strategies that were used to reduce stress during the COVID-19 outbreak is an important topic. Stress coping styles are general predispositions in dealing with stress that result from learning based on past experiences. The most important 
factor that eases work for healthcare workers is self-confidence [29]. In this study, the most commonly used coping method was self-confident approaches, which is compatible with the study results.

Studies reported that anxiety and depressive disorders were observed more frequently in women [30]. Zhou et al. reported that, female students have suffered from greater psychological impact, as well as higher levels of stress, anxiety, and depressive symptoms, during the COVID-19 outbreak [31]. Wang et al. reported that during the COVID-19 pandemic, anxiety in women was three times higher than that in men [25]. In another study in Turkey, women had higher rates of anxiety and depressive disorder than men [24]. Similarly, in our study, female healthcare workers had higher anxiety levels due to the COVID-19 outbreak. This finding is consistent with previous studies that found that women were at a higher risk of anxiety. The psychiatric impact during the COVID-19 pandemic may be greater on women.

\section{Limitations}

Nonetheless, our study has some limitations. First, the homogeneity of the group was disrupted by including responses not just from doctors, but also from other healthcare employees. Additionally, the lack of differentiation between active workers in the field and those who were not actively working may be listed as a limitation.

\section{Conclusion}

The BAI scores of doctors were lower compared with others, and stress coping levels were similar. Healthcare workers were observed to mostly develop positive coping attitudes during the COVID-19 pandemic. The high level of anxiety scores in addition to the life status of daily fighting against COVID-19 suggests that female healthcare workers must cope with psychological distress. Healthcare workers comprise one of the most important groups that require protection during pandemics. However, the information of every worker with regard to psychological symptoms is not the same; hence, informing them of trauma, depression and anxiety symptoms is important. Their physical and psychological health is important both for themselves and the patients they treat.

Conflict of interest: The authors have no conflicts of interest to declare.

Funding: No person or organization supported this work financially. The authors have no relationship with any sponsor or commercial company involved in the study.

\begin{tabular}{|l|r|l|}
\hline \multicolumn{2}{|c|}{ Author Contributions } & \multicolumn{1}{|c|}{ Author Initials } \\
\hline SCD & Study Conception and Design & DDO, AKS \\
\hline AD & Acquisition of Data & DDO, AKS \\
\hline AID & Analysis and Interpretation of Data & AKS \\
\hline DM & Drafting of Manuscript & DDO, AKS \\
\hline CR & Critical Revision & DDO \\
\hline
\end{tabular}

\section{References}

1. World Health Organization [internet]. Novel coronavirus (2019-nCoV) technical guidance $2020 . \quad$ Available at: https://www.who.int/emergencies/diseases/novel-coronavirus-2019/ technical-guidance (Access Date: May 25, 2020)

2. Centers for disease control and prevention [internet]. 2019 novel coronavirus, Wuhan, China. Information for healthcare professionals 2020. Available at: https://www.cdc.gov/coronavirus/2019 nCoV/hcp/index.html (Access Date: May 25, 2020)

3. World Health Organization (WHO) [internet]. Coronavirus disease 2019 (COVID-19) situation report-29 2020. Available at: https://www.who.int/docs/defaultsource/coronaviruse/situation-reports/20200218-sitrep-29-covid-19.pd (Access Date: May 25, 2020)

4. Huang C, Wang Y, Li X, Ren L, Zhao J, Hu Y, et al. Clinical features of patients infected with 2019 novel coronavirus in Wuhan, China. Lancet 2020;395(10223):497-506. https://doi.org/10.1016/S0140-6736(20)30183-5

5. Norris FH. Range, magnitude and duration of the effects of disasters on mental health: review update 2005. New Hampshire: Dartmouth Medical School and National Center for PTSD; 2005.

6. Greenberg N, Docherty M, Gnanapragasam S, Wessely S. Managing mental health challenges faced by healthcare workers during covid-19 pandemic. BMJ 2020;368:m1211. https://doi.org/10.1136/bmj.m1211

7. Lee SM, Kang WS, Cho AR, Kim T, Park JK. Psychological impact of the 2015 MERS outbreak on hospital workers and quarantined hemodialysis patients. Compr Psychiatry 2018;87:123-7. https://doi.org/10.1016/j.comppsych.2018.10.003

8. Chang D, Xu H, Rebaza A, Sharma L, Dela Cruz CS. Protecting health-care workers from subclinical coronavirus infection. Lancet Respir Med 2020;8(3):e13. https://doi.org/10.1016/S2213-2600(20)30066-7

9. Artan I. Organizational stress factors and a practice on managers. Istanbul: Bassen Culture and Education; 1986.

10. Wu P, Fang Y, Guan Z, Fan B, Kong J, Yao Z, et al. The psychological impact of the SARS epidemic on hospital employees in China: exposure, risk perception, and altruistic acceptance of risk. Can J Psychiatry 2009;54(3):302-11. https://doi.org/10.1177/070674370905400504

11. Park JS, Lee EH, Park NR, Choi YH. Mental health of nurses working at a government-designated hospital during a MERS-CoV outbreak: a cross sectional study. Arch Psychiatr Nurs 2018;32(1):2-6. https://doi.org/10.1016/j.apnu.2017.09.006

12. Folkman S, Lazarus RS, Pimley S, Novacek J. Age differences in stress and coping processes. Psychol Aging 1987;2(2):171-84. https://doi.org/10.1037/0882-7974.2.2.171 
13. Atkinson RL, Atkinson RC, Smith EE, Bem DJ, Nolen-Hoeksema S. Introduction to psychology. third ed., Ankara: Arkadas; 2006.

14. Folkman S, Lazarus RS. An analysis of coping in a middle-aged community sample. J Health Soc Behav 1980;21(3):219-39.

15. Sahin NH, Durak A. The adaptation of the stress coping styles inventory to the university students. J Turkish Psychol. 1995;10(34):56-73.

16. Beck AT, Epstein N, Brown G, Steer RA. An inventory for measuring clinical anxiety: psychometric properties. J Consulting Clin Psychol 1988;56(6):893-7. https://doi.org/10.1037/0022-006X.56.6.893

17. Ulusoy M, Sahin NH, Erkmen H. Turkish version of the Beck Anxiety Inventory: psychometric properties. J Cogn Psychother 1998;12:16372.

18. Khalid I, Khalid TJ, Qabajah MR, Barnard AG, Qushmaq IA. Healthcare workers emotions, perceived stressors and coping strategies during a MERS-CoV outbreak. Clin Med Res 2016;14(1):7-14. https://doi.org/10.3121/cmr.2016.1303

19. Gee S, Skovdal M. The role of risk perception in willingness to respond to the, 2014-2016 West African Ebola outbreak: a qualitative study of international health care workers. Glob Health Res Policy 2017;2:21. https://doi.org/10.1186/s41256-017-0042-y

20. Lai J, Ma S, Wang Y, Cai Z, Hu J, Wei N, et al. Factors associated with mental health outcomes among health care workers exposed to coronavirus disease 2019. JAMA Netw Open 2020;3(3):e203976. https://doi.org/10.1001/jamanetworkopen.2020.3976

21. Zhu J, Sun L, Zhang L, Wang H, Fan A, Yang B, et al. Prevalence and influencing factors of anxiety and depression symptoms in the firstline medical staff fighting against COVID-19 in Gansu. Front Psychiatry 2020;11:386. https://doi.org/10.3389/fpsyt.2020.00386

22. Moghanibashi-Mansourieh A. Assessing the anxiety level of Iranian general population during COVID-19 outbreak. Asian J Psychiatr 2020;51:102076. https://doi.org/10.1016/j.ajp.2020.102076

23. Wang C, Pan R, Wan X, Tan Y, Xu L, Ho CS, et al. Immediate psychological responses and associated factors during the initial stage of the 2019 coronavirus disease (COVID-19) epidemic among the general population in China. Int J Environ Res Public Health 2020;17:1729. https://doi.org/10.3390/ijerph17051729

24. Ozdin S, Bayrak Ozdin S. Levels and predictors of anxiety, depression and health anxiety during COVID-19 pandemic in Turkish society: the importance of gender. Int J Soc Psychiatry 2020;66(5):504-11. https://doi.org/ 10.1177/0020764020927051

25. Wang Y, Di Y, Ye J, Wei W. Study on the public psychological states and its related factors during the outbreak of coronavirus disease 2019 (COVID-19) in some regions of China. Psychology. Health \& Medicine 2020;1-10. https://doi.org/10.1080/13548506.2020.1746817

26. Salari N, Hosseinian-Far A, Jalali R, Vaisi-Raygani A, Rasoulpoor S, Mohammadi M, et al. Prevalence of stress, anxiety, depression among the general population during the COVID-19 pandemic: a systematic review and meta-analysis. Global Health $2020 ; 16: 57$. https://doi.org/10.1186/s12992-020-00589-w

27. Malta M, Rimoin AW, Strathdee SA. The coronavirus 2019-nCoV epidemic: is hindsight 20/20?. EClinicalMedicine 2020;20:100289. https://doi.org/10.1016/j.eclinm.2020.100289

28. Huang JZ, Han MF, Luo TD, Ren AK, Zhou XP. Mental health survey of 230 medical staff in a tertiary infectious disease hospital for COVID19. Zhonghua Lao Dong Wei Sheng Zhi Ye Bing Za Zhi 2020;38(3):192-5. https://doi.org/10.3760/cma.j.cn121094-20200219-00063

29. Aoyagi Y, Beck CR, Dingwall R, Nguyen-Van-Tam JS. Healthcare workers' willingness to work during an influenza pandemic: a systematic review and meta-analysis. Influenza Other Respir Viruses 2015;9(3):120-30. https://doi.org/10.1111/irv.12310

30. Alexander JL, Dennerstein L, Kotz K, Richardson G. Women, anxiety and mood: a review of nomenclature, comorbidity and epidemiology. Expert Rev Neurotherapeutics 2007;7(1):45-58. https://doi.org/10.1586/14737175.7.11s.S45

31. Zhou SJ, Zhang LG, Wang LL, Guo ZC, Wang JQ, Chen JC, et al. Prevalence and socio-demographic correlates of psychological health problems in Chinese adolescents during the outbreak of COVID-19. Eur Child Adolescent Psychiatry 2020;29:749-58. https://doi.org/10.1007/s00787-020-01541-4 